\title{
LEGALITY OF ATTACKS AGAINST HUMAN SHIELDS IN ARMED CONFLICT
}

\author{
Eduard Hovsepyan*
}

\begin{abstract}
The numerous examples of the use of human shields in armed conflicts display the contemporaneity of the problem discussed in this article and the need for a recipe to effectively combat the continuing commission of this war crime. In spite of the fact that an absolute prohibition on the use of human shields in international armed conflicts exists, as enshrined in the Geneva Conventions of 1949 and Additional Protocol I, consequences of unlawful resort to human shields remain inconsistent. Thus, the present article will determine when and under what circumstances attacks carried out against human shields are lawful, and which principles of international humanitarian law must be taken into account by the attacking party.
\end{abstract}

\section{A. INTRODUCTION}

'No matter what cause one defends, it will suffer permanent disgrace if one resorts to blind attacks on crowds of innocent people.' (Albert Camus) ${ }^{1}$

This article will examine the issues relating to the legality of attacks against human shields in armed conflict. It will focus primarily on international armed conflict, exploring the legal framework and principles of international humanitarian law ('IHL') governing the obligations of attacking and defending parties. The focus is placed on international armed conflict ('IAC') because of the customary international law status which the norms pertaining to the use of human shields have obtained over time in that context. Nevertheless, given the growing number and impact of conflicts of a non-international character, an attempt will be made to address rules relevant to that context, providing examples to better illustrate the present findings.

Authors have often referred to the term 'human shields' as:

The intentional use of a party to a conflict of one or more human beings, usually civilians, or captured members of the adversary's forces ... placed between the adversary and themselves in a way meant to deter an attack against the forces using the human shields, for fear of killing or harming the unarmed shields. The shields are in effect hostages used for strategic purposes. ${ }^{2}$

\footnotetext{
* Eduard Hovsepyan holds an LLM in Public International Law with a specialisation in Human Rights and Humanitarian Law from Leiden University and a BA in International Relations from Sofia University. He is currently an LLM candidate in Bulgarian National Law at Sofia University. The author would also like to thank Joe Powderly, Assoc. Prof. at Leiden University, for his guidance while writing this article.

${ }^{1}$ Albert Camus, Algerian Chronicles (Harvard University Press 2013) 27.
} 
However, this definition may not be entirely accurate. As will be examined in section $\mathrm{C}$, not all human shields are intentionally placed as such against their will by defending parties. In some cases, protected persons voluntarily expose themselves to attacks in an attempt to deter the attacking party from carrying out an attack. This is why Schmitt's more concise definition will be preferred, which states that ' $[\mathrm{h}]$ uman shielding involves the use of persons protected by international humanitarian law, such as prisoners of war or civilians, to deter attacks on combatants and military objectives. ${ }^{3}$ This includes all possible situations of use of human shields, namely moving civilians to protect a military target, deploying military targets among civilians (so-called 'unknowing human shields') or simply benefiting from the voluntary exposure of civilians to military attacks.

The issue proves to be extremely topical given the frequent violations of the existing absolute prohibition of the use of human shields. Violations include notorious cases such as 'Operation Iraqi Freedom' in 2003 and the NATO campaign in Yugoslavia in 1999 when Serbian civilians took up positions on the bridges of Belgrade to prevent them from being bombed. ${ }^{4}$ Apart from these more well-known examples, other illustrations of similar conduct include the use of involuntary human shields by the Tamil Tigers in Sri Lanka, or for instance, the deployment of arms and munitions among civilians by Hezbollah militiamen in the Second Lebanon War in $2006 .^{5}$ Widely discussed also is the use of human shields in Gaza, as well as in the ongoing Syrian conflict. ${ }^{6}$

The following sections will delve into several distinct but interrelated issues. To begin with, the main instruments regulating the prohibition of human shields will be examined. The relevant provisions of the Hague Regulations, Geneva Conventions and Additional Protocol I ('AP I') will be explored, as well as the Rome Statute.

After outlining the ban on the use of human shields and the relevant principles of IHL, those rules will be applied to examples from international practice in section $\mathrm{C}$ to better illustrate the findings of the article. Most importantly, the section will assess the legal status of human shields, analysing the levels of protection enjoyed by the persons forming the shield under

\footnotetext{
${ }^{2}$ Victor Conde, A Handbook of International Human Rights Terminology (2nd edn, University of Nebraska Press 2004) 114; eg in Amnon Rubinstein and Yaniv Roznai, 'Human Shields in Modern Armed Conflicts: The Need for a Proportionate Proportionality’ (2011) 22 Stanford Law \& Policy Review 93, 94.

${ }^{3}$ Michael Schmitt, 'Human Shields in International Humanitarian Law' (2009) 47 Columbia Journal of Transnational Law 292, 309.

${ }^{4}$ Stéphanie Bouchié de Belle, 'Chained to Cannons or Wearing Targets on Their T-shirts: Human Shields in International Humanitarian Law' (2008) 90 International Review of the Red Cross 883, 884.

${ }^{5}$ See also Matthew Ezzo and Amos Guiora, A Critical Decision Point on the Battlefield - Friend, Foe, or Innocent Bystander, Security: A Multidisciplinary Normative Approach (Martinus Nijhoff/Brill 2009) 103-107.

${ }^{6}$ UNHRC, 'Report of the Special Rapporteur on the Promotion and Protection of Human Rights and Fundamental Freedoms while Countering Terrorism' (16 June 2015) UN Doc A/HRC/29/51 [51].
} 
IHL. Furthermore, the section will consider whether human shields retain their civilian protection or could be considered as taking direct participation in hostilities and how this affects the attacking party's obligations. A distinction between involuntary and voluntary human shields will be made. The purpose of this section is to examine under what conditions the attacks would be lawful, focusing on the principles of distinction and proportionality, as well as on the obligation to take precautionary measures under AP I.

Finally, the article arrives at two pivotal findings. First, both voluntary and involuntary human shields generally retain their civilian status with an exception for voluntary shields in certain circumstances. Second, the principle of proportionality continues to apply despite the use of human shields. Nevertheless, a less restrictive proportionality assessment is possible when civilians are voluntarily protecting military objectives. The application of these two principles would not be precluded by an issuing of an advance warning by the attacking party.

\section{B. LEGAL FRAMEWORK}

\section{The Hague Regulations}

Under the Hague Conventions of 1899 and 1907 an explicit reference to the term 'human shield' does not exist. However, Article 23 of the 1907 Hague Convention Respecting the Law and Customs of War on Land states that '[a] belligerent is forbidden to compel the nationals of the hostile party to take part in the operations of war directed against their own country'. ${ }^{7}$ It is worth noting that initially this provision was not included in the Draft Convention. It was suggested by the German delegation in furtherance of the principle accepted in 1899 concerning forced participation of the population of an occupied territory in military operations against their country. ${ }^{8}$ It extended this principle to all citizens of the occupied state's territory, including even foreign subjects who might have been in the service of the hostile party before the commencement of the war. ${ }^{9}$ The Austro-Hungarian delegation proposed an amendment to this text, limiting the prohibition to compel the nationals of the hostile party to take part as combatants only. ${ }^{10}$ Thus the Austro-Hungarian delegation desired a clear distinction to be drawn between 'operations of war' - in which the population of the

\footnotetext{
${ }^{7} 1907$ Hague Convention (IV) Respecting the Laws and Customs of War on Land and Its Annex: Regulations Concerning the Laws and Customs of War on Land (adopted 18 October 1907, entered into force on 26 January 1910) art 23.

${ }^{8}$ Carnegie Endowment for International Peace, The Proceedings of the Hague Peace Conferences: Volume I (OUP 1920) 97.

${ }^{9}$ ibid.

${ }^{10}$ ibid.
} 
hostile state cannot be compelled to take part - and certain 'military services' which, in some cases, a belligerent should be free to impose on the civilian population, according to that delegation. ${ }^{11}$ Nevertheless, this view was not shared by the majority and the German proposal was accepted by 23 votes in favour, nine against and one abstention. ${ }^{12}$ The adoption of this text and the rejection of Austria-Hungary's proposal proves the drafters' intention to outlaw any act aimed at using nationals of the other belligerent party in the conduct of hostilities, regardless of whether the nationals were used as combatants or not. In light of this, it may be assumed that the prohibition of using these nationals as human shields against their own state is included in this provision. As General Jonkheer den Beer Poortugael stated during the Conference, '[if] it is true that war is made by State upon State, let us not force inhabitants to mingle in the struggle; above all let us not force them to commit villainies'. ${ }^{13}$

However, Germany was arguably the first state to violate this provision. During World War I an official commission of the Belgian government blamed the German forces of using 'human screens'. ${ }^{14}$ The Germans were accused of placing civilians in front of their military lines in order to prevent the Belgian army from attacking them. The Commission further stipulated that '[i]f it be not permissible to compel a man to fire on his fellow citizens, neither can he be forced to protect the enemy and to serve as a living screen'. ${ }^{15}$

In sum, given the wide condemnation that Germany faced for its actions, which were tantamount to using human shields, it can be concluded that an implicit prohibition on the use of human shields could be traced back to the beginning of the $20^{\text {th }}$ century despite the difference in terminology. Thus, the Hague Regulations succeeded in setting a common standard according to which nationals of a belligerent party must not be coerced in any way to contribute to the military effort of the hostile party. Yet the numerous atrocities which followed during the World Wars made it clear that the principle of protection of the civilian population and hors de combat should be further regulated. This prompted the convening of the Geneva Conferences and the adoption of the four conventions of 1949.

\section{The Geneva Conventions of 1949}

\footnotetext{
${ }^{11}$ ibid.

${ }^{12}$ Carnegie Endowment for International Peace, The Proceedings of the Hague Peace Conferences: Volume III (OUP 1921) 12.

${ }^{13}$ ibid 11.

${ }^{14}$ Neve Gordon and Nicola Perugini, 'The Politics of Human Shielding: On the Resignification of Space and the Constitution of Civilians as Shields in Liberal Wars' (2016) 34 Environment and Planning D: Society and Space $168,171-72$.

15 ibid.
} 
The outcome of the Conferences in 1949 was the adoption of two articles which, again without expressly referring to the term 'human shields', precluded the use of civilians and hors de combat for the purpose of rendering certain points or areas immune from military operations. Although bearing resemblance to the previous Article 23 of the Hague Regulations, the new approach introduced some important novelties, but was limited only to the scope of the Third and Fourth Geneva Conventions. It was enshrined in articles 23 and 28 , respectively.

Article 23 of the Geneva Convention (III) Relative to the Treatment of Prisoners of War provides that ' $[\mathrm{n}] \mathrm{o}$ prisoner of war may at any time be sent to, or detained in areas where he may be exposed to the fire of the combat zone, nor may his presence be used to render certain points or areas immune from military operations'. ${ }^{16}$ The chosen phrase 'at any time' shows the provision is absolute. ${ }^{17}$ The detaining party has the obligation to evacuate prisoners not only following capture in accordance with Article 19 of the same Convention, ${ }^{18}$ but also whenever any shift in the front may result in prisoners being in the combat zone. ${ }^{19}$

Article 28 of the Geneva Convention (IV) Relative to the Protection of Civilian Persons in Time of War is more concise, stating that ' $[\mathrm{t}]$ he presence of a protected person may not be used to render certain points or areas immune from military operations' ${ }^{20}$ The main purpose of this article is to distinguish between ruses of war, which are permissible, and acts of barbarity, which are unlawful. ${ }^{21}$ Article 24 of the Hague Convention (IV) Respecting the Law and Customs of War on Land states that '[r]uses of war and the employment of measures necessary for obtaining information about the enemy and the country are considered permissible'. ${ }^{22}$ However, ruses of war are not a valid pretext for breaking the law. Pictet elaborates that the lawfulness of ruses of war depends on the observance of the laws and customs of war, which are themselves based on the principle of respect for the civilian

\footnotetext{
161949 Geneva Convention (III) Relative to the Treatment of Prisoners of War (adopted 12 August 1949, entered into force 21 October 1950) 75 UNTS 135 (GCIII) art 23.

${ }^{17}$ Jean Pictet, Commentary to the III Geneva Convention Relative to the Treatment of Prisoners of War (International Committee of the Red Cross 1960) 187.

18 'Prisoners of war shall be evacuated, as soon as possible after their capture, to camps situated in an area far enough from the combat zone for them to be out of danger'.

${ }^{19}$ Pictet (n 17) 187.

${ }^{20}$ Geneva Convention (IV) Relative to the Protection of Civilian Persons in Time of War (adopted 12 August 1949, entered into force 21 October 1950) 75 UNTS 287 (GCIV) art 28.

${ }^{21}$ Jean Pictet, Commentary to the IV Geneva Convention Relative to the Protection of Civilian Persons in Time of War (International Committee of the Red Cross 1958) 208.

${ }^{22} 1907$ Hague Convention (IV) Respecting the Laws and Customs of War on Land and Its Annex: Regulations Concerning the Laws and Customs of War on Land (adopted 18 October 1907, entered into force on 26 January 1910) (HCIV) art 24.
} 
population. Consequently, the presence of civilians must never be used to render immune from military operations objectives which are liable to be attacked. ${ }^{23}$

Hence, it can be observed that an absolute ban on the use of civilians as means of protecting military targets existed in the Geneva Conventions of 1949. Still, the fact remains that an explicit prohibition regarding the use of human shields was not discussed at the time. The travaux préparatoires show that the term was not clearly brought up during the negotiations. The representatives of the International Committee of the Red Cross ('ICRC') put forward the idea regarding Draft Article 21 (Article 23 of Geneva Convention III) that prisoners of war should have the same protection against air bombardment and other hazards of war as the civilian population, whilst the Irish delegation expressed the view that any protective measure taken on behalf of the civilian population should be extended to prisoners of war in cases where the camp administration was not in a position to provide adequate protection for them. ${ }^{24}$ The substance of Draft Article 25a (Article 28 of Geneva Convention IV) was not discussed. It was not until 1977 when AP I was adopted and an explicit provision pertaining to human shields was introduced.

\section{Additional Protocol I of 1977}

Prior to the adoption of AP I, the ban on the use of human shields was enshrined in the Third and Fourth Geneva Conventions of 1949. This meant that the scope of the prohibition concerned only prisoners of war and protected persons. On the other hand, Article 51(7) of AP I concerns the civilian population as a whole, extending the ban not only ratione personae, but also ratione materiae. ${ }^{25}$

This is where the word 'shield' first appeared. It was laid out in Article 51(7) which stipulates that 'the presence or movements of the civilian population or individual civilians shall not be used to render certain points or areas immune from military operations, in particular in attempts to shield military objectives from attacks or to shield, favour or impede military operations'. ${ }^{26}$ It further states that 'the Parties to the conflict shall not direct the movement of the civilian population or individual civilians in order to attempt to shield military objectives from attacks or to shield military operations'. ${ }^{27}$ Thus, this provision

\footnotetext{
${ }^{23}$ Pictet (n 17) 208.

24 'Final Record of the Diplomatic Conference of Geneva of 1949' (Geneva 21 April 1949-12 August 1949) (vol II(A)) 254.

${ }^{25}$ Bouchié de Belle (n 4) 886.

${ }^{26}$ Protocol Additional to the Geneva Conventions of 12 August 1949, and relating to the Protection of Victims of International Armed Conflicts (adopted 8 June 1977, entered into force on 7 December 1978) 1125 UNTS 3 (AP I) art 51(7).

${ }^{27}$ ibid.
} 
reiterates the absolute prohibition set out in the previous Geneva Conventions and yet the use of human shields does not necessarily exclude the possibility of a legitimate attack carried out against them. ${ }^{28}$ This is a focal point for the analysis on the legality of attacks against the shielding party.

During the negotiations for the adoption of the two Additional Protocols, it was highlighted that special emphasis should be attached to the problem of protection of the civilian population. Mr. Balken, who participated in the negotiations in his role as vicepresident of the German Federal Republic, expressed the view that 'world public opinion expected important results from the work of the Conference: a substantial reaffirmation and development of international humanitarian law, an impressive demonstration of the universal character of the Geneva Conventions'. ${ }^{29}$ He further noted that, consequently, Article 51 (draft Article 46) should be regarded as a key provision in the Protocol and should be adopted. ${ }^{30}$ This approach clearly demonstrates the willingness of certain delegations to face the issue of civilian protection in armed conflict - an issue which also includes the use of human shields. Similar positions were also taken by the delegations of Greece, Romania, Iraq and the German Democratic Republic. ${ }^{31}$

However, Article 51 was not adopted by consensus. The French delegation opposed its adoption, claiming that some of the provisions of the article, including paragraph 7 of the Final Act (Draft Article 46(5)), would 'by their very complexity seriously hamper the conduct of defensive military operations against an invader and prejudice the exercise of the inherent right of legitimate defence recognised in Article 51 of the Charter of the United Nations. ${ }^{32}$ It further argued that the determination of "clearly separated and distinct military objectives' as laid down in paragraph 7 of the Final Act could be unrealisable on certain occasions. ${ }^{33}$ Thus, the delegation perceived the article as going 'beyond its humanitarian aim' and that it was likely to seriously impair the inherent right of legitimate self-defence. ${ }^{34}$ Eventually, in spite of some dissensions, the article was adopted with 77 votes in favour, 16 abstentions, and one vote against - that of France. ${ }^{35}$

\footnotetext{
${ }^{28}$ Judith Butler, 'Human Shields' (2015) 3 London Review of International Law 223, 224.

${ }^{29}$ 'Official Records of the Diplomatic Conference on the Reaffirmation and Development of International Humanitarian Law Applicable in Armed Conflicts' (Geneva 20 February 1974-10 June 1977) (vol V) 131.

${ }^{30}$ ibid.

31 ibid.

${ }^{32}$ Diplomatic Conference on the Reaffirmation and Development of International Humanitarian Law (n 29) (vol VI) 162 .

33 ibid.

${ }^{34}$ ibid.

${ }^{35}$ ibid.
} 
In its Commentary, the ICRC stated that fears expressed by the French delegation could not be justified. ${ }^{36}$ The approach of the ICRC seems more reasonable since the right to self-defence should not include the use of measures that would be contrary to IHL. Indeed, the French delegation's proposal gained little support during the Conference. The dismissal of the French proposal also indicates the international community's concern as to the importance of this provision and hence the vast majority of states ruled out the possibility that it might be left out of the final text. But even more importantly, the right to self-defence was clearly perceived as not encompassing the use of civilians and civilian objects for shielding military targets.

Finally, it can be concluded that the importance of the regulations regarding the protection of the civilian population had grown immensely by the time the Protocol was adopted. This is manifested by the fact that in the draft the ICRC stated that Article 51 would be among the provisions to which no reservations could be made. ${ }^{37}$ Even though the Conference deleted all provisions relating to the possibility of making reservations, in its Commentary the ICRC specified that reservations to this article, even partial ones, could jeopardise the balance achieved with difficulty between the divergent views that emerged in the Diplomatic Conference. ${ }^{38}$ Thus, any such reservation would be against the object and purpose of this 'indispensable provision'. ${ }^{39}$ These findings are essential in terms of the issue of human shields, because they extend to paragraph 7 .

The last remaining step in the codification of the prohibition of the use of human shields was its definition as a war crime entailing individual criminal responsibility under international criminal law. This step was at last taken in 1998 with the adoption of the Rome Statute of the International Criminal Court (ICC).

\section{The Rome Statute of 1998}

The use of human shields during an international armed conflict is characterised as a war crime under Article 8(2)(b)(xxiii). It is defined as 'utilizing the presence of a civilian or other protected person to render certain points, areas or military forces immune from military operations, ${ }^{40}$

\footnotetext{
${ }^{36}$ Yves Sandoz, Christophe Swinarski and Bruno Zimmermann, Commentary on the Additional Protocols of 8 June 1977 to the Geneva Conventions of 12 August 1949 (International Committee of the Red Cross 1987) 615. ${ }^{37}$ ibid 616.

38 ibid.

${ }^{39} \mathrm{ibid}$

${ }^{40}$ Rome Statute of the International Criminal Court (adopted on 17 July 1998, entered into force 1 July 2002, last amended 2010) 2187 UNTS 38544 (Rome Statute) art 8(2)(b)(xxiii).
} 
Examining the drafting history of the ICC Statute, it is worth mentioning the statement of the Kuwaiti representative who, by addressing the frequent use of human beings as shields by some countries, proposed that such acts should be listed as a crime against humanity. ${ }^{41}$ This proposal demonstrates the concern by this particular delegation caused by the continuing violations of rules pertaining to human shields as a result of widespread and systematic policies. This particularly follows from practice during the Gulf War (1991) and the Yugoslav Wars.

Another important aspect is whether this prohibition applies to both involuntary and voluntary human shields. The ICC Elements of Crimes provide four elements of this war crime, namely:

1. The perpetrator moved or otherwise took advantage of the location of one or more civilians or other persons protected under the international law of armed conflict.

2. The perpetrator intended to shield a military objective from attack or shield, favour or impede military operations.

3. The conduct took place in the context of and was associated with an international armed conflict.

4. The perpetrator was aware of factual circumstances that established the existence of an armed conflict. $^{42}$

There appears to be no requirement that the civilians are taken as hostages, or that they have chosen voluntarily to act as human shields. Rather, the essential element is the intention to use the presence of humans as shields to shelter a military objective from attack or to shield, favour or impede military operations. ${ }^{43}$ The difficulties in this case arise from the assessment of the intent of the defending party which must be made on a case-by-case basis. ${ }^{44}$

There has also been some discussion in relation to Element 1. Some delegations expressed the view that the wording 'or otherwise took advantage of the location' failed to capture both the situation where civilians are already present at a certain place and the situation where civilians voluntarily move to a place. ${ }^{45}$ Therefore they suggested, by referring

\footnotetext{
41 'Summary records of the meetings of the Committee of the Whole' UN Diplomatic Conference of Plenipotentiaries on the Establishment of an International Criminal Court (Rome 15 June-17 July 1998) (17 June 1998) UN Doc A/CONF.183/13 (vol II) 149.

42 'Elements of Crimes' Official Records of the Assembly of States Parties to the Rome Statute of the International Criminal Court (New York 3-10 September 2002) ICC-ASP/1/3/Add.1 (vol II) 143.

${ }^{43}$ Bouchié de Belle (n 4) 889.

44 ibid.

${ }^{45}$ Knut Dörmann, Louise Doswald-Beck and Robert Kolb, Elements of War Crimes under the Rome Statute of the International Criminal Court: Sources and Commentary (CUP 2003) 344.
} 
to AP I, that the word 'location' in Element 1 be changed to 'presence or movements' ${ }^{46}$ Other delegations claimed that the proposed formulations would be too restrictive and that 'location' is not only sufficient but it is broader than 'presence' and would also cover every variation of location. ${ }^{47}$ They also underlined that what is important in this crime is not the type of movement or location being used, but the intended use, as expressed in Element 2. With that clarification, the proposed elements for this crime were accepted without change. ${ }^{48}$ These debates prove that the prohibition extends to all types of human shields discussed in this article. In sum, the Rome Statute makes no distinction between involuntary and voluntary human shields, meaning that any use of human shields in an international armed conflict could potentially entail individual criminal responsibility.

The Rome Statute completes the codification of the rules relating to human shields, forming the contemporary legal framework alongside AP I. The prohibition is clear and vested in the international instruments discussed above. This framework delineates definition of human shields and the consequences for the defending party. The next question that needs to be addressed is what are the corresponding obligations of the attacking party? In section $\mathrm{C}$ the rules of distinction, proportionality and precaution (focusing on advance warnings) will be considered in order to ascertain specific conclusions regarding the attacking party's rights and obligations.

\section{Human Shields in non-international armed conflict}

Before moving on to section $\mathrm{C}$, it is necessary to briefly mention the rules regulating the use of human shields in non-international armed conflict ('NIAC'). As stated in the introduction, the reason the current study focuses on the rules applicable in IACs is not because they are deemed to be of greater importance. On the contrary, the occurrence of international armed conflicts has substantively decreased in comparison to NIACs. Furthermore, a number of the examples mentioned in sections $\mathrm{A}$ and $\mathrm{C}$ have taken place in the context of a NIAC. Hence, the focus on the norms of international armed conflict can be explained by the fact that all relevant provisions contained in the Hague Regulations, Geneva Conventions and AP I pertaining to human shields are considered to reflect customary IHL. ${ }^{49}$

The problem concerning the use of human shields in NIACs used to be the lack of an express prohibition in Additional Protocol II ('AP II'). Initially, a similar provision to that

\footnotetext{
46 ibid.

47 ibid.

48 ibid 345.

49 Jean-Marie Henckaerts and Louise Doswald-Beck, Customary International Humanitarian Law: Volume I (International Committee of the Red Cross 2005) 337.
} 
contained in AP I was included in the draft protocol. Draft Article 26(5) specified that ' $[\mathrm{t}] \mathrm{he}$ parties to the [non-international] conflict shall not use the civilian population or civilians in attempts to shield military objectives from attacks. ${ }^{, 50}$ Despite this initial draft, the adopted version of the text reflected a simplified version of Draft Article 26, proposed by Pakistan. ${ }^{51}$ It excluded paragraph 5 from the final version of the article. However, the exclusion cannot undermine the importance of the provision relating to human shields. This is evident from the statement made by the Norwegian delegation whereby the rejection of the most important parts of Article 26 were 'serious blows to the humanitarian cause'. ${ }^{52}$ It further added that the intrinsic value of Protocol II was to be found in the provisions for protection of the civilian population and civilian objects and that the adoption of some parts of Article 26 nevertheless represented some very modest progress. ${ }^{53}$

Yet some provisions of AP II indirectly address this issue. Like Article 19 of the Third Geneva Convention, Article 5(2)(c) of AP II provides for the evacuation of persons deprived of their liberty from combat areas so that they are not exposed to danger. Additionally, Article 13(1) stipulates that the civilian population and individual civilians 'shall enjoy general protection against the dangers arising from military operations.'

Moreover, the use of human shields has often been associated with the taking of hostages. ${ }^{54}$ The prohibition of hostage taking has been incorporated in Article 4(2)(c) of AP II, as well as in Common Article 3 to the Geneva Conventions of 1949. Common Article 3 is not only considered to be customary IHL, but it also lays down the minimum standards to be respected during any armed conflict. ${ }^{55}$ It can also be argued that the norms enshrined in Common Article 3 have obtained the status of erga omnes obligations, having been defined as 'elementary considerations of humanity'. ${ }^{56}$ Scholars go even further by claiming the provisions laid down in Common Article 3 satisfy the criteria to be designated as jus cogens norms and are thus applicable at all times, in all circumstances and to all states and from which no derogation at any time is permitted. ${ }^{57}$ Therefore, even if states initially rejected the

\footnotetext{
${ }^{50}$ Diplomatic Conference on the Reaffirmation and Development of International Humanitarian Law (n 29) (vol I) 40 .

51 ibid (vol I) 81 .

52 ibid (vol VII) 206.

${ }^{53}$ ibid.

${ }^{54}$ Sandoz, Swinarski, and Zimmermann (n 36) 680.

${ }_{55}^{5}$ Prosecutor v Tadic (Appeals Judgment) ICTY-94-1-A (15 July 1999) [70].

${ }^{56}$ Military and Paramilitary Activities in and against Nicaragua (Nicaragua $v$ United States of America), Merits, Judgment [1986] ICJ Rep 14 [218].

${ }^{57}$ Rafael Nieto-Navia, International Peremptory Norms (Jus Cogens) and International Humanitarian Law in Man's Inhumanity to Man: Essays on International Law in Honour of Antonio Cassese (Kluwer Law International 2003) 638.
} 
proposed inclusion of the provision concerning the use of human shields in the final version of AddiAP II, practice has developed to adapt the rules on the use of human shields in international armed conflict to those regulating NIACs. ${ }^{58}$ Consequently, it can be deduced that the general legal norms governing the use of human shields are applicable in both international and non-international armed conflicts. This conclusion is also supported by the ICRC which has explicitly reminded parties to both international and non-international armed conflicts that the prohibition of using human shields extends to both types of conflict. ${ }^{59}$

However, some discrepancies do occur and the most notable exception concerns the possibility that this crime be prosecuted before the ICC under the Rome Statute. The prohibition discussed in section B.4 pertains only to crimes committed during an international armed conflict.

Having outlined the legal framework governing the use of human shields in both international and non-international armed conflicts, the analysis can now move on to the next section where the conclusions so far will be opposed to the principles of IHL which the attacking party must observe. This will be illustrated with examples from both types of conflict.

\section{LEGALITY OF ATTACKS UNDER THE PRINCIPLES OF IHL}

In this section, the relevant principles of IHL are applied in answering the main question as to what constitutes a legitimate attack against human shields. Three steps will be undertaken in achieving this task. First, the status of human shields under international law in relation to the principle of distinction will be examined. In particular, the issue of whether human shields directly take part in hostilities will be analysed. Second, taking into consideration the legal status of human shields, the question whether human shields should be excluded from the proportionality assessment will be addressed. Finally, the matter whether the issuing of an advance warning by the attacking party affects its obligations vis-à-vis the civilians forming the human shield will be discussed.

\section{Direct participation in hostilities}

Generally speaking, civilians are persons who are not members of armed forces or militias. ${ }^{60}$ Their protection under IHL is not unlimited as they waive their civilian protection when they

\footnotetext{
58 Jean-Marie Henckaerts and Louise Doswald-Beck, (n 49) 338.

${ }^{59}$ Nieto-Navia (n 57) 339.

${ }^{60}$ Henckaerts and Doswald-Beck (n 49) 17. For militias see: GCIII art 4A(2): 'Members of other militias and members of other volunteer corps, including those of organized resistance movements, belonging to a Party to the conflict and operating in or outside their own territory'
} 
engage in direct participation of hostilities ('DPH'). ${ }^{61}$ Consequently, civilians can be lawfully targeted and, as opposed to combatants, prosecuted for their mere participation in hostilities. $^{62}$

DPH is an ambiguous concept. Overall, it is perceived as composed of acts of war, which by their nature or purpose are likely to cause actual harm to personnel or equipment of the enemy armed forces. ${ }^{63}$ This rule was further elaborated by the ICRC with the adoption of its Interpretive Guidance on the Notion of Direct Participation in Hostilities under International Humanitarian Law ('ICRC Guidance on DPH'). A crucial novelty introduced therein was the inclusion of three cumulative criteria that define DPH: a threshold of harm, a direct causal link between the act and the harm likely to result, and a belligerent nexus. ${ }^{64}$ Although heavily criticised, ${ }^{65}$ it is claimed that the Guidance adopted a neutral, impartial, and balanced approach, resisting proposals coming from both extremes, whilst ensuring that the final interpretation would still be commensurate with the foundational principles of IHL. ${ }^{66}$ Furthermore, the three conditions do not seem to be disputed. In his critique on the constitutive elements in the ICRC Guidance on DPH, Schmitt agrees with all three constitutive elements in principle, noting only that the Guidance defines them too restrictively. ${ }^{67}$ Therefore, given the fact that the constitutive elements are seemingly not disputed in their essence, they can be used as basic guidelines in the present analysis. In applying these elements, the analysis will take into account - but will not be limited to - the ICRC's interpretation.

\section{a) Involuntary human shields and direct participation in hostilities}

It is hardly conceivable that a person, who is held and positioned in front of a military objective against his will, can be considered as taking DPH. An unequivocal example of use of involuntary human shields can be provided in the case of the Tamil Tigers ('LTTE') in Sri Lanka. In May 2009, forced to retreat by government offensive operations, the LTTE drove civilians into a narrow strip of land on Sri Lanka's north-eastern coast, effectively using

\footnotetext{
61 ibid 19-20.

${ }^{62}$ Nils Melzer, Interpretive Guidance on the Notion of Direct Participation of Hostilities under International Humanitarian Law (International Committee of the Red Cross 2009) 84.

${ }^{63}$ Sandoz, Swinarski, and Zimmermann (n 36) 619.

${ }^{64}$ Melzer (n 62) 46.

${ }^{65}$ See Michael Schmitt, 'The Interpretive Guidance on the Notion of Direct Participation in Hostilities: A Critical Analysis' (2010) 1 Harvard National Security Journal 5, 39-43.

${ }^{66}$ Shannon Bosch, 'Targeting Decisions Involving Voluntary Human Shields in International Armed Conflicts in Light of the Notion of Direct Participation in Hostilities' (2013) 46 Comparative and International Law Journal of Southern Africa 447, 457.

${ }^{67}$ Nils Melzer, 'Keeping the Balance between Military Necessity and Humanity: A Response to Four Critiques of the ICRC's Interpretive Guidance on the Notion of Direct Participation in Hostilities' (2010) 42 New York University Journal of International Law and Politics 831, 857.
} 
several hundred thousand people as human shields. In addition, the LTTE shot at and injured or killed many of those trying to flee from the war zone to government-held territory. ${ }^{68}$ In another example prior to these events, Iraq became arguably the first state to announce publicly that it would resort to the use of human shields during the First Gulf war. ${ }^{69}$ Iraqi forces captured foreign citizens and treated them as hostages. Many of them, together with Iraqi citizens, were used as human shields, placed at or near military and strategic facilities to deter attacks. $^{70}$

In instances such as these, the involuntary human shields do not meet the requirements for DPH. Being equated to hostages, there appears to be no belligerent nexus between the shields and the shielding party. Dinstein argues that acting under duress and absent complicity, involuntary human shields cannot be regarded as civilians DPH and their use as such even carries criminal consequences. ${ }^{71}$ Given the almost unanimous agreement among scholars on the subject, ${ }^{72}$ it can be concluded that involuntary human shields retain their civilian protection under IHL.

\section{b) Voluntary human shields and direct participation in hostilities}

The position of voluntary human shields is less clear. ${ }^{73}$ Scholars are divided as to whether voluntary shields are civilians protected against direct attack or civilians DPH and therefore targetable. $^{74}$

Authors such as Dinstein maintain that voluntary human shields are DPH and thus waive their civilian protection. ${ }^{75}$ Advocates of this approach argue that voluntary shields take affirmative steps to frustrate harm to objects (or persons) that make a direct contribution to

\footnotetext{
${ }^{68}$ Human Rights Watch, 'Sri Lanka events of 2009' (2010) <www.hrw.org/world-report/2010/countrychapters/sri-lanka> accessed 25 January 2017.

${ }^{69}$ Paolo Fusco, 'Legal Status of Human Shields' [2003] Centro Studi per la Pace

$<$ files.studiperlapace.it/spp_zfiles/docs/20050125105209.pdf> accessed 25 January 2017.

${ }^{70}$ ibid. See also UNGA Res 46/314 (17 December 1992) UN Doc A/RES/46/134 [2(d)].

${ }^{71}$ Yoram Dinstein, The Conduct of Hostilities under the Law of International Armed Conflict (2nd edn, CUP 2010) 154.

${ }^{72}$ Committee on the Conduct of Hostilities under International Humanitarian Law, 'Interim Report on the Challenges of 21st Century Warfare' (2014) International Law Association, $15<$ www.ila-

hq.org/download.cfm/docid/806C2DED-87FF-4744-8CC8EDAF47787AE6> accessed 24 January 2017. By identifying the contemporary problems pertaining to the use of human shields, the Study Group reports that the issue of human shields circles around the problem whether voluntary shields are civilians protected against direct attack and does not mention involuntary ones. An opposite view, however, seems to be expressed in the British Joint Service Manual of the Law of Armed Conflict. Although not reflecting the issue of direct participation, it states that '[e]ven where human shields are being used, [citation omitted] the proportionality rule must be considered. However, if the defenders put civilians or civilian objects at risk by placing military objectives in their midst or by placing civilians in or near military objectives, this is a factor to be taken into account in favour of the attackers in considering the legality of attacks on those objectives'. In Ministry of Defence, Manual of the Law of Armed Conflict (JSP 383) at 2.7.2. See also Schmitt (n 3 ) 49.

${ }^{73}$ Bouchié de Belle (n 4) 892.

${ }^{74}$ ILA Study Group (n 72) 24.

${ }^{75}$ Yoram Dinstein 'Direct Participation in Hostilities' (2013) 18 Tilburg Law Review 3, 14.
} 
the military effort and, in doing so, contribute to the military action in a direct causal way. ${ }^{76}$ Hence, it is difficult to interpret their behaviour as anything but direct participation. ${ }^{77}$ Additionally, the Israeli High Court of Justice in Public Committee against Torture in Israel held on the issue of human shields that:

If they are doing so because they were forced to do so by terrorists, those innocent civilians are not to be seen as taking a direct part in the hostilities. ... However, if they do so of their own free will, out of support for the terrorist organization, they should be seen as persons taking a direct part in the hostilities. ${ }^{78}$

Nonetheless, this view cannot be fully supported. Relying on the ICRC's definition of 'direct participation', 'actual harm' must be caused to enemy personnel or military equipment. ${ }^{79}$ Voluntary human shields act passively and do not strike the enemy directly. ${ }^{80}$ Nevertheless, the ICRC Guidance on DPH considers that while acts of voluntary human shields may cause harm, ${ }^{81}$ it would arguably only be indirect. ${ }^{82}$ This view is highly controversial. ${ }^{83}$ Arguably such a direct link is possible, but only as far as the threat posed is immediate and imminent. This may include a scenario where voluntary shields deliberately create a physical obstacle hindering enemy ground operations or protect a weapon about to strike the enemy forces. Authors have illustrated this imminent threat by describing a soldier advancing toward a tank with a civilian strapped to it, forcing the soldier to choose between his own death and using lethal force against someone normally immune to attack. ${ }^{84}$

There appears to be no consistent practice with regard to the question if voluntary human shields amount to DPH. The phenomenon of voluntary human shields received considerable media coverage during the 2003 Iraq war when foreign peace activists travelled to strategic locations in Iraq, such as oil refineries and power stations, in order to forestall American military strikes. ${ }^{85}$ Even though most of these activists eventually fled the theatre of

\footnotetext{
${ }^{76}$ Schmitt (n 3) 41.

77 ibid.

${ }^{78}$ Cited in Rewi Lyall, 'Voluntary Human Shields, Direct Participation in Hostilities and the International

Humanitarian Law Obligations of States’ (2008) 9 Melbourne Journal of International Law 313, 320.

${ }^{79}$ Sandoz, Swinarski, and Zimmermann (n 36) 619.

${ }^{80}$ Bouchié de Belle (n 4) 894.

${ }^{81}$ Melzer (n 62) 56.

82 ibid 57.

${ }^{83}$ Schmitt (n 65).

${ }^{84}$ Michael Skerker, 'Just War Criteria and the New Face of War: Human Shields, Manufactured Martyrs, and Little Boys with Stones' (2004) 3 Journal of Military Ethics 27, 36.

85 Josiane Haas, 'Voluntary Human Shields: Status and Protection under International Humanitarian Law', in Roberta Arnold and Pierre-Antoine Hildbrand (eds), International Humanitarian Law and the 21st Century's Conflicts: Changes and Challenges (Edis 2005) 191.
} 
war, Schmitt argues they would have forfeited their protection if they had remained. ${ }^{86}$ US officials claimed that 'you certainly could argue that since [voluntary human shields are] working in the service of the Iraqi government, they may, in fact, have crossed the line between combatant and non-combatant'. ${ }^{87}$ The US citizens among the activists were prosecuted for having acted as voluntary human shields in Iraq. ${ }^{88}$

Nevertheless, the threshold for such determination should be extremely high and it should be presumed that voluntary human shields normally do not reach it. In order for the causal link between the conduct and the resulting harm to exist, the actual harm in question must be brought about in one single step. ${ }^{89}$ Although the term 'one single step' used by the drafters of the Interpretive Guidance is not entirely clear, it is suggested that it entails a clear link between the act and the ensuing harm. ${ }^{90}$ Unless the voluntary human shield poses a physical obstacle preventing ground forces from advancing, or shields a weapon about to strike, the link remains indirect. It remains doubtful whether such a direct link existed in the case of Operation Iraqi Freedom.

The concept of DPH should be applied restrictively. ${ }^{91}$ Although it is possible that actions of voluntary human shields amount to $\mathrm{DPH}$, the threshold for such determination should be set high. ${ }^{92}$ Accordingly, each individual's actions should be assessed on a case-bycase basis as to whether they constitute $\mathrm{DPH}^{93}$ and it cannot be assumed that all civilians voluntarily protecting certain military objectives can be lawfully attacked. This finding impacts on the principle of proportionality, described as the most important extension or extrapolation of the principle of distinction. ${ }^{94}$

\section{Proportionality assessment}

Following the analysis made above it can be deduced that, generally, due to the protection human shields are entitled to, the principle of proportionality remains applicable. But even if

\footnotetext{
${ }^{86}$ Michael Schmitt, 'The Conduct of Hostilities During Operation Iraqi Freedom: an International Humanitarian Law Assessment' (2003) 6 Yearbook of International Humanitarian Law 73, 100.

87 'Human shields in Iraq - Briefing by the Senior Defence Official \& Staff, US Defence Department' (Iraq Watch, 26 February 2003) <www.iraqwatch.org/government/US/Pentagon/dod-shields-022603.htm> accessed 3 June 2016.

${ }^{88}$ Bosch (n 66) 472-473.

${ }^{89}$ Melzer (n 62) 53.

${ }^{90}$ Schmitt (n 65) 30.

91 'In case of doubt a person shall be protected against direct attack.' See Dieter Fleck, The Manual of International Humanitarian Law (3rd edn, OUP 2003) 33.

92 Similarly, the drafters of the ICRC Guide on DPH found that '[d]epending on the circumstances, it may also be questionable whether voluntary human shielding reaches the required threshold of harm'. In Melzer (n 62) 57.

93 Prosecutor v Tadic (Judgment) ICTY-94-1-T (7 May 1997) [616].

${ }^{94}$ Dinstein (n 75) 5.
} 
the concept of human shields as civilians DPH can be dismissed, the question arises whether they should still be included in the proportionality assessment.

Arguments have been made that even though human shields retain their civilian protection, they should be excluded from the proportionality equation due to the military nature of the targets they shield. ${ }^{95}$ This seems to be the approach taken by the US with the adoption of the latest 2015 Department of Defense Law of War Manual (DoD Manual). The DoD Manual states that the use of human shields does not alter the legal obligations of the attacking party to discriminate in carrying out attacks against the enemy. ${ }^{96}$ If human shields are considered in proportionality calculations, then a higher anticipated military advantage is required to render the attack lawful. Thus, human shields would alter the attacking party's legal obligations. ${ }^{97}$ As a result, according to the US DoD Manual, human shields should be excluded from the proportionality assessment. ${ }^{98}$ However, this conclusion seems inaccurate as the following two sections will demonstrate.

\section{a) Involuntary human shields in the proportionality assessment}

Scholars such as Rubinstein and Roznai have distinguished between involuntary and unknowing human shields, arguing that the proportionality assessment must be adapted to the circumstances. ${ }^{99}$ This distinction is made in relation to the taking of precautionary measures (see section C.3). An advance warning would make the unknowing civilians aware that they are situated near a military target and enable them to find shelter. When involuntary human shields protect the military objective, the warning is intended to inform the party using the human shields that their objective is about to be targeted in spite of the use of civilian presence. ${ }^{100}$ Finally, these authors affirm that in both cases the shields retain their civilian protection and the present author supports this conclusion.

However, Rubinstein and Roznai go even further, asserting that when the use of involuntary or unknowing human shields is part of a widespread or systematic policy, the measure of proportionality must be adjusted. ${ }^{101}$ They argue that when civilians are placed as shields next to a military objective, the proportionality assessment cannot be detached from the shielding party's actions and ought to take into account the incentive to illegally use

\footnotetext{
95 Banu Bargu, 'Human Shields' (2013) 12 Contemporary Political Theory 277, 284-285.

${ }^{96}$ US Department of Defence, Law of War Manual (Department of Defence 2015) 198.

97 ibid 245.

98 Adil Haque, 'The Defense Department's Indefensible Position on Killing Human Shields' (Just Security, 22 June 2015) <www.justsecurity.org/24077/human-shields-law-war-manual/> accessed 19 June 2016.

${ }^{99}$ Rubinstein and Roznai (n 2) 121.

100 ibid.

101 ibid.
} 
civilians as human shields. ${ }^{102}$ This concept of 'adjustment' of the proportionality assessment is also put forward by Dinstein. He contends that although the principle of proportionality applies to involuntary human shields, the test of what amounts to excessive injury to civilians must be 'relaxed'. ${ }^{103}$

This approach seems to be misguided. It might have some practical implications in terms of removing the incentive of the shielding party to take advantage of the protected status civilians enjoy, ${ }^{104}$ but it contradicts core IHL principles, such as the principle of nonreciprocity. This principle has been explicitly pointed out in Article 51(8) in AP I whereby any violation of the obligations enshrined in Article 51 (including the use of human shields) shall not release the parties to the conflict from their legal obligations with respect to civilians.

Dinstein refers to the text of Article 51(8) as a 'curious provision that seems to punish the complying party for an adversary's bad faith'. ${ }^{105}$ He finds support in the text of the UK Manual on the Law of Armed Conflict which states that 'the enemy's unlawful activity may be taken into account in considering whether the incidental loss or damage was proportionate to the military advantage expected'. ${ }^{106}$ Moreover, he uses the Israeli bombardment over Beirut in 1982 in order to highlight that the high number of civilian casualties was not necessarily excessive given the fact that the military targets were placed amongst the civilian population. ${ }^{107}$

Again, this approach seems flawed. As for the first argument put forward, although exceptions exist, the majority of military manuals provide for respect for the principle of nonreciprocity. ${ }^{108}$ Furthermore, in its study on customary IHL, the ICRC presented abundant evidence to conclude that this principle reflects customary IHL. ${ }^{109}$ As for the second argument, one might argue that the bombings over Beirut do not represent contemporary IHL pertaining to the use of and attacks against human shields. For instance, during the NATO campaign against Yugoslavia in 1999, the Allied forces were reluctant to make such bold statements despite the use of human shields by the Serbs. On the contrary, the 2000 NATO

\footnotetext{
102 ibid.

${ }^{103}$ Dinstein (n 71) 155.

${ }^{104}$ US Law of War Manual (n 96) 245.

${ }^{105}$ Dinstein (n 75) 154-155.

106 ibid 155 .

107 ibid citing Doswald-Beck.

${ }^{108}$ See eg Australia's Commanders' Guide and Defence Force Manual (1994); Canada's LOAC Manual (1999); Colombia's Basic Military Manual (1995); France's LOAC Manual (2001); Dutch Military Manual (1993), Jean-Marie Henckaerts and Louise Doswald-Beck, Customary International Humanitarian Law, Volume II: Practice (International Committee of the Red Cross 2005) 3188-3190.

${ }^{109}$ Henckaerts and Doswald-Beck (n 49) Rule 140.
} 
Secretary-General's report affirmed that the selection of targets was carefully reviewed at multiple levels of command in order to ensure compliance with international law. ${ }^{110}$ In addition, the report stated that the concern to avoid unintentional damage was a principal constraining factor and many targets were not attacked because the risk to non-combatants was considered too high despite the reported use of human shields by the Serbs. ${ }^{111}$ It can be deduced from these statements that the use of human shields did not alter the proportionality assessment. Even if on some occasions these statements do not reflect reality, ${ }^{112}$ the fact that NATO officials conceded that attacks against human shields cause excessive damage (as that over Beirut) ensures that it is perceived that human shields should not presuppose a looser assessment.

It is thus contended that proportionality assessment should remain strict and in no way are involuntary human shields to be excluded from the equation.

\section{b) Voluntary human shields in the proportionality assessment}

In the analysis so far, it was determined that generally voluntary human shields, like involuntary ones, do not engage in DPH (see section C.1(b)). Nevertheless, the next question that arises is whether the same proportionality assessment criteria are applicable to voluntary human shields.

Indeed this is the case in most scenarios. Logically, the proponents of the notion that voluntary human shields are DPH support the view that 'it would be incongruent to suggest they should nevertheless count in proportionality calculations'. ${ }^{113}$ The main argument in support of the view that voluntary human shields should be excluded from the proportionality assessment is that should they be excluded, they would be unable to achieve their goals and thus lose their incentive to expose themselves to risk because they would not alter the obligations of the attacking party nor pose any legal obstacles in carrying out the attacks. ${ }^{114}$ However, given the fact that under the current legal framework there is no provision explicitly addressing the issue of voluntary human shields, it appears they remain covered by

\footnotetext{
${ }^{110}$ Lord Robertson of Port Ellen, 'Kosovo One Year On, Achievement and Challenge' (NATO 2000) $<$ www.nato.int/kosovo/repo2000/report-en.pdf> accessed 4 June 2016.

111 ibid.

${ }^{112}$ See eg the attack carried out in the Korisa village when 87 civilians were killed and approximately 60 were injured. Although it was stated that there was some information indicating that displaced Kosovar civilians were forcibly concentrated within a military camp in the village of Korisa as human shields, NATO claimed to have believed that the area was completely cleared of civilians; In Tania Voon, 'Pointing the Finger: Civilian Casualties of NATO Bombing in the Kosovo Conflict' (2001) 16 American University International Law Review 1083, 1111.

${ }^{113}$ Michael Schmitt, 'War, Technology and the Law of Armed Conflict' (2006) 82 International Law Studies $137,152$.

${ }^{114}$ Dinstein (n 71) 153.
} 
the general legal framework pertaining to human shields. ${ }^{115}$ Hence, the protection normally afforded to involuntary human shields would apply to voluntary ones. As a result, voluntary human shields must not be excluded from the proportionality assessment.

Practice also seems to support this view. During the 1999 Yugoslavian war, there were occasions when hundreds of civilians flocked onto the bridges in Belgrade in order to shield them from NATO airstrikes. ${ }^{116}$ In relation to these events, the NATO commander was adamant that 'no responsible commander wishes to kill civilians ... Every day we did our very, very best to limit collateral damage and limit the loss of life on the adversary's side'.117 If commanders perceived voluntary shields as DPH and not to be included in the proportionality assessment, they would not have been considered as possible collateral damage.

Nevertheless, another factor needs to be taken into consideration, known as 'the inherent risk run by voluntary human shields'. ${ }^{118}$ Although voluntary human shields do not lose civilian protection under IHL, they are at greater risk of being targeted by virtue of their proximity to a military target. ${ }^{119}$ Hence an analogy may be drawn between voluntary human shields and workers in armament or munitions factories. ${ }^{120}$ In both cases, the individuals continue to benefit from their civilian protection, but as long as the attacking party can prove that the military necessity to attack the military objective was in proportion to the civilian losses incurred, the operation would be lawful in spite of the greater number of casualties expected. $^{121}$

The main concern in this regard is the definition of "excessive". The workers in armament or munitions factories, as well as the voluntary human shields, run the inherent risk'. Nonetheless, the former (similarly to involuntary human shields) lack the volitional element to shield. On the other hand, voluntary human shields are fully aware that they are shielding a military objective and have the intention to do so. Thus, it seems reasonable to expect that what amounts to an excessive attack in normal circumstances might not be excessive if the casualties were voluntary human shields. ${ }^{122}$ It can therefore be deduced that a

\footnotetext{
${ }^{115}$ Michael Newton and Larry May, Proportionality in International Law (OUP 2014) 214.

116 ibid 202.

117 ibid quoting Lieutenant General Michael Short.

${ }^{118}$ Bouchié de Belle (n 4) 896.

119 ibid 897.

120 ibid 896-897.

${ }^{121}$ Haas (n 85) 210.

${ }^{122}$ During the drafting of the ICRC Guide on DPH one of the experts shared a similar view opining that the question of proportionality was better phrased as the question of "excessive" civilian casualties. In determining how many casualties would be excessive, one always had to take into account the concrete situation and context.
} 
somewhat looser proportionality test should be acceptable on the occasion that the civilians voluntarily expose themselves to military attacks. This, however, is not meant to support Dinstein's notion that attacks against military objectives may proceed as if the voluntary human shield were not there. ${ }^{123}$ It is argued that proportionality must generally remain applicable although more civilian damage is to be accepted when determining the threshold for an "excessive" attack. Inevitably, particularly when voluntary human shields are involved, proportionality calculations would depend on a unique set of circumstances. ${ }^{124}$

Consequently, the bridges in Belgrade could have been legitimately targeted with a bigger number of casualties anticipated in comparison to a hypothetical situation in which they were held there against their will. It should be noted that children must not be considered voluntary human shields under any circumstances as they cannot be considered as having a will of their own. ${ }^{125}$ Moreover, a looser assessment must be applied only in exceptional circumstances given the blurred lines between voluntary and involuntary human shields. Only when there is sufficient evidence that civilians are shielding a military target on their own free will should the shields be considered voluntary (see section C.2(c)). Therefore, in most cases the stricter, regular proportionality assessment would apply.

The observations so far can be concluded by reiterating that the principle of proportionality should generally remain applicable to human shields in all circumstances, as opposed to the approach stipulated in the US DoD Manual (see section C.2). The proportionality assessment should remain strict in the case of involuntary human shields while a looser assessment is conceivable only when civilians voluntarily expose themselves to attacks. Moreover, despite the existing notions that voluntary human shields are DPH and should not be considered in proportionality calculations, practice shows that they do enjoy a form of protected status in the theatre of war. ${ }^{126}$ Only on rare occasions when their actions can directly contribute to the damage suffered by the enemy can they be considered as DPH and thus eligible to be attacked for the time they do so. Moreover, in the very recent update of the US DoD Manual, the Department of Defense seemingly changed its approach and deleted the controversial paragraph cited in the present article. DoD General Counsel Jennifer O'Connor stated in November 2016 that the then forthcoming change 'will provide greater

\footnotetext{
What was excessive in ordinary circumstances was, according to him, not necessarily excessive if the casualties were voluntary human shields. In ICRC, Summary Report of the Second Expert Meeting on the Notion of Direct Participation in Hostilities (The Hague, 25/26 October 2004) 7.

${ }^{123}$ Dinstein (n 75) 14.

124 Haas (n 85) 210.

${ }^{125}$ Schmitt (n 3) 57.

${ }^{126}$ Bosch (n 66) 473.
} 
clarity on the DoD legal view of human shields, noting that whether voluntary or involuntary, civilian "human shields" would not be considered to be directly participating in hostilities and would not thereby lose their protections from attack. Specifically, the revised Manual clarifies that the proportionality rule applies to these individuals' ${ }^{127}$ Although this change also gave rise to criticism, ${ }^{128}$ it supports the findings in the present article and abides by the contemporary legal standards governing the use of human shields. In addition, the edited DoD Manual takes the stance that only in some cases, which are to be assessed on a case-bycase basis, can voluntary human shields be considered as DPH. ${ }^{129}$ Whether the new Manual will also adopt the approach of a looser proportionality test with regard to voluntary human shields is yet to be seen. The new edited Manual already includes a curious provision that leaves room for a similar interpretation whereby '[a]lthough human shields who are civilians are to be considered as civilians in determining whether a planned attack would be excessive, enemy use of voluntary human shields may be considered as a factor in assessing the legality of an attack. ${ }^{130}$ The evolution of the US stance on human shields as illustrated by the DoD Manual can serve as evidence for the unification of view and practice in this part of IHL in line with the findings in the present article.

\section{c) Distinction between Voluntary/Involuntary human shields}

Referring to the findings in the previous two sections, it is deemed necessary to examine the issue of distinction between voluntary and involuntary human shields, an issue rather overlooked.

For instance, there have been very recent reported cases of Syrian rebel groups using caged civilians as human shields in order to deter attacks against their strongholds around Damascus. ${ }^{131}$ However, one could also argue that it is possible for civilians to consent to be detained in such cages. On the one hand, this would influence the public opinion in relation to potential attacks against the human shields. On the other hand, taking into account the

\footnotetext{
${ }^{127}$ Jennifer M O'Connor, 'Applying the Law of Targeting to the Modern Battlefield', New York University School of Law (New York, 28 November 2016)<www.defense.gov/Portals/1/Documents/pubs/Applying-theLaw-of-Targeting-to-the-Modern-Battlefield.pdf $>$ accessed 14 February 2017

${ }^{128}$ See Charles J Dunlap Jr, 'A Squarable Circle?: The Revised DoD Law of War Manual and the Challenge of Human Shields' (15 December 2016) <www.justsecurity.org/35597/squarable-circle-revised-dod-law-warmanual-challenge-human-shields/> accessed 14 February 2017.

${ }^{129}$ US Department of Defence, Law of War Manual (Department of Defence 2015, edited December 2016) 270. 'However, the enemy use of voluntary human shields may be considered as a factor in assessing the legality of an attack. Based on the facts and circumstances of a particular case, the commander may determine that persons characterized as voluntary human shields are taking a direct part in hostilities'. 130 ibid 280.

${ }^{131}$ AFP, 'Syrian Rebels Using Caged Civilian Captives as Human Shields' (The Telegraph, 2 November 2015) $<$ www.telegraph.co.uk/news/worldnews/middleeast/syria/11971269/Syrian-rebels-using-caged-pro-Assadcaptives-as-human-shields.html $>$ accessed 5 June 2016.
} 
conclusions from sections C.2(a) and C.2(b), these actions could also alter the proportionality assessment.

Vice versa, what if civilians appear to shield a military target voluntarily, whilst in reality they are coerced to do so? Then the coercing party would not lose credibility while the civilians risk their lives to an even bigger extent than if they were undoubtedly held against their will. Thus, when no reliable information proving a specific volitional element to shield is available, the presumption must be that those civilians act involuntarily. ${ }^{132}$

It is problematic that such an act cannot fall under perfidy as defined in the Hague Regulations $^{133}$ and AP I. ${ }^{134}$ The prohibition enshrined in these instruments only concerns the killing, injuring or capturing of an adversary by resort to perfidy. ${ }^{135}$ In the present case the adversary suffers no such harm. As a result, the attacking party could be misled without any legal consequences. Depending on the circumstances, this could further hamper the attacking party's military operations. Additionally, it might lead to more casualties.

In sum, given the findings that a difference concerning the legality of attacks against voluntary and involuntary human shields does exist, it can be concluded that the legal framework pertaining to perfidy should be expanded to include acts as exemplified in this section.

\section{Advance warnings}

The principle of precautions in attack is the final relevant principle regarding the lawfulness of attacks. In order to comply with this principle, when a choice between several military objectives for obtaining similar military advantage is possible, the attacking party must select the objective which is not shielded by civilians. ${ }^{136}$ However, if a shielded military target has no alternative and the strike would be proportionate, then Article 57(2)(c) of AP I demands effective advance warnings to be given, 'unless circumstances do not permit [so].' These warnings could make a significant difference in reducing the number of civilian casualties, especially in the cases of voluntary or unknowing human shields.

But what constitutes an effective advance warning? It is not easy to determine what kind of advance warning would be considered effective, nor is it clear how specific and direct the warning has to be. ${ }^{137}$ For example, the Commission of Inquiry on Lebanon has stated that if a military force is serious in its attempts to warn civilians to evacuate because of impending

\footnotetext{
${ }^{132}$ Dinstein (n 71) 154.

${ }^{133}$ HCIV, art 23(b).

134 ibid art 37.

${ }^{135}$ Sandoz, Swinarski, and Zimmermann (n 36) 432.

${ }^{136}$ API, art 57(3).

${ }^{137}$ Dinstein (n 71) 144.
} 
danger, it should take into account how they expect the civilian population to carry out the instructions. ${ }^{138}$ It also noted the importance of the warning being timely, giving the civilians sufficient time to evacuate and ensuring they are not attacked while evacuating. ${ }^{139}$ Thus it seems difficult to determine the specificity of an advance warning, reconciling the protection of the civilian population with the gaining of military advantage. ${ }^{140}$ The proposed adequacy of an advance warning depends on whether it reaches those who are exposed to danger, whether it is clear and credible, and specific enough regarding the location to be affected. ${ }^{141}$ Moreover, the requirement that the warning be timely should also imply that it must not be made too early as then the upcoming attack could be conceived as false. ${ }^{142}$

Given that an advance warning is made, what are the consequences for the human shields if they remain in the vicinity of the military objective after the warning was issued? Some commentators argue that in the case of voluntary human shields, a refusal to abandon the shielded object constitutes DPH. ${ }^{143}$ Furthermore, Israeli practice in Lebanon shows Israeli officials believed that everyone who remained behind after the dropping of the leaflets that served as advance warnings was linked to Hezbollah, and therefore a legitimate target of attack. ${ }^{144}$ The leaflets also alerted that any pickup truck or truck travelling south of the Litani River will be suspected of transporting rockets and weapons and may be bombed. ${ }^{145}$

The present author firmly disagrees with these approaches. Firstly, the taking of precautionary measures should not be confused with the principle of distinction. Therefore, if voluntary human shields do not fulfil the criteria for DPH as described above, they would still not be participating directly even if an advance warning is issued. If civilians retain their civilian protection while shielding a military target, the warning itself does not deprive them of this protection. A proportionality assessment should be made before carrying out the attack. Hence, an advance warning merely informs the voluntary shields that a potential attack against them has been considered proportionate. It is up to them to decide whether they

\footnotetext{
${ }^{138}$ UNHRC 'Report of the Commission of Inquiry on Lebanon pursuant to Human Rights Council resolution S2/1' UN Doc A/HRC/3/2 (23 November 2006) 40. 
would remain in the area to be attacked under these circumstances. It is part of the inherent risk they face when engaging in shielding military targets. As for the second approach taken in the conflict in Lebanon, it totally disregards the principle of distinction. In addition, it is widely open for abuse. For instance, Israel stated that during the bombings in 2006 the advance warnings made were large-scale, exceeding the demands of international law in their attempts to keep the number of fatalities among the population to a bare minimum. ${ }^{146}$ In reality, many people were unable to leave either because they were part of a vulnerable group, had no means of transportation or simply because the destruction of infrastructure made it impossible. ${ }^{147}$ Many of those who left were attacked on their way out. ${ }^{148}$ Therefore, the assumption that an advance warning could give the attacking party carte blanche to attack indiscriminately an entire area without taking into consideration the possibilities for the civilians used as shields to benefit from the warning is inadmissible. Even if the warnings were effective, there is no legal basis in IHL whereby an advance warning precludes respect for the principles of IHL. Article 57(5) of AP I explicitly states that no provision in Article 57 (including advance warnings) may be construed as authorising any attacks against the civilian population, civilians or civilian objects. Although in the example given Israel is not a party to AP I, ${ }^{149}$ the ICRC maintains that all obligations with respect to the principle of distinction and the conduct of hostilities remain applicable even if civilians remain in the zone of operations after a warning has been issued. ${ }^{150}$ Thus, neither voluntary nor involuntary/unknowing human shields can be excluded from the proportionality assessment on the basis that they have remained in the vicinity of a military objective after an advance warning was given.

A more problematic issue arises in relation to the obligations of the attacking party compared to those of the defending party when it comes to precautionary measures. It is argued that the prohibition of the use of human shields and the obligation to remove the civilian population from the vicinity of military objectives ${ }^{151}$ provide for dissimilar

\footnotetext{
${ }^{146}$ Reuven Erlich, 'Hezbollah's Use of Lebanese Civilians as Human Shields: The Extensive Military Infrastructure Positioned and Hidden in Populated Areas. From Within the Lebanese Towns and Villages Deliberate Rocket Attacks Were Directed Against Civilian Targets in Israel', Intelligence and Terrorism Information Center at the Center for Special Studies (CSS) 2006, 55.

${ }^{147}$ Lebanon Commission of Inquiry (n 138) 40.

148 ibid.

${ }^{149}$ ICRC, 'Parties to AP I' (ICRC, 22 June 2006)

$<$ www.icrc.org/applic/ihl/ihl.nsf/States.xsp?xp_viewStates=XPages_NORMStatesParties\&xp_treatySelected=4 $70>$ accessed 22 June 2016.

${ }^{150}$ Henckaerts and Doswald-Beck (n 49) 65.

${ }^{151}$ API, art 58(a).
} 
standards. ${ }^{152}$ While the violation of the former requires a specific intent to shield, the violation of the latter is not that strict ('endeavour to remove'). As a result, the obligations for the defending party seem to resemble recommendations rather than strict obligations. ${ }^{153}$ This disparity in the legal weight of the provisions has been reflected in the criticism against the Goldstone report. ${ }^{154}$ In fact, the Report only concludes that Palestinians were not forced to act as human shields and fails to mention the obligation to remove civilians from the vicinity of military objectives. ${ }^{155}$ Nevertheless, when discussing the legality of attacks against human shields, the principle of non-reciprocity should be taken into account (see section C.2(a)). Although it can be agreed that a disparity does exist, the law, as it stands, allows the carrying out of attacks in light of the principles of distinction, proportionality and precaution, regardless of whether the enemy abides by those principles. Therefore, although some intermingling of civilians and combatants is virtually inevitable, ${ }^{156}$ this does not release the attacking party from its own obligations.

In sum, the issuing of an advance warning does not preclude parties from applying the principles of distinction and proportionality as demonstrated in the Lebanon example. As for the disparity between the obligations of the attacking and the defending party, the principle of non-reciprocity remains applicable. Hence the criticism towards the Goldstone report relating to that point is more of a political nature than of a legal one.

\section{CONCLUSION}

In conclusion, attacks against human shields can be lawful, but only if they are in compliance with the basic principles of IHL. The principles of non-reciprocity, distinction, proportionality and precaution were examined as the main pillars of IHL which contain the legal framework pertaining to human shields. In applying those principles to the phenomenon of human shields, an attempt was made to give guidance on the legality of attacks against human shields under the current IHL framework. Firstly, it was ascertained that human shields in general continue to enjoy civilian protection. Involuntary/unknowing human shields retain their civilian protection under any circumstances. On certain rare occasions, voluntary human shields can be considered as DPH thereby losing their civilian protection, but only if their actions cause direct danger to the attacking party. Nevertheless, in most cases

\footnotetext{
152 Schmitt (n 3) 28-29.

${ }^{153}$ Dinstein (n 71) 145.

${ }^{154}$ Laurie Blank, 'The Application of IHL in the Goldstone Report: A Critical Commentary' (2009) 12

Yearbook of International Humanitarian Law 347, 388.

${ }^{155}$ UN Fact Finding Commission on Gaza (n 141) 120.

${ }^{156}$ Dinstein (n 71) 145.
} 
both voluntary and involuntary human shields are not directly targetable. Secondly, it was explored how the application of the principle of distinction affects the proportionality assessment. Both involuntary and voluntary human shields should be included in the proportionality assessment as a corollary of their continuing civilian protection. A less restrictive proportionality assessment is possible for voluntary human shields due to their own choice to expose themselves to risk. Naturally, voluntary human shields, which satisfy the requirements for $\mathrm{DPH}$, would not be taken into account in the equation. Whether they satisfy the DPH criteria should be determined on a case-by-case basis and if there is no sufficient evidence for an intent to shield a military object, then the rule of doubt should be applied. Hence human shields are involuntary until proven otherwise. Finally, it was maintained that the issuing of advance warnings does not exclude the attacking party's obligations under the principles of distinction and proportionality. Regardless of whether the shields are voluntary or involuntary, the issuing of an advance warning does not deprive civilians of their civilian protection or alter the proportionality assessment. Besides, even if the defending party fails to comply with its obligations under IHL, the attacking party must still abide by them in light of the principle of non-reciprocity.

So, is the contemporary legal framework adequate? It has been argued that human shields present a practical critique of international law by exposing its ambiguous distinctions and the political implications that follow from their constitutive character. ${ }^{157}$ Other authors have insisted that there is no need for a new framework, since DPH is an adequate tool to deal with this issue. ${ }^{158}$ Perhaps both sides are right. In applying the contemporary rules of IHL to the problem of human shields it was proved that the current legal framework has the capacity to deal with this phenomenon. Nevertheless, this does not mean there is no room for improvement. Regulations on voluntary human shields should be codified in order to avoid abuse and ambiguity. It was shown that the drafters of the contemporary IHL instruments failed to specifically address this question. As a result, ambiguity renders interpretation of norms related to voluntary human shields open to abuse. Therefore, an explicit agreement should be reached defining the levels of protection voluntary human shields are entitled to in order to facilitate legal compliance from the parties to an armed conflict. Moreover, in the analysis it was pointed out that if a distinction in the levels of protection enjoyed by involuntary and voluntary human shields truly exists, then the deception by the defending party should amount to perfidy. Nowadays warfare has evolved in a way that perfidy not only

\footnotetext{
${ }^{157}$ Bargu (n 95) 7.

${ }^{158}$ Haas (n 85) 211.
} 
leads to physical harm to the attacker, but could also impose stricter legal obligations. Finally, more pressure should be put on defending parties to act under Article 58 of AP I in order to prevent to the biggest extent possible difficult choices before the attacking parties. The obligations of the defending party to prevent human shielding should be put on equal terms as those of the attacking party not to attack them indiscriminately.

Yet the present author merely presented the legality of attacks against human shields in an ideal manner where IHL is applied in good faith. In practice, IHL violations occur in almost any armed conflict. Furthermore, even if the potential attack is legal, would the attacking party overcome the moral and political constraints in launching it? In the case of human shields, the attacking party does not estimate the approximate collateral damage which might occur, but it directly aims at and intentionally targets an objective where the casualties are almost certain to result. ${ }^{159}$ The current discussion did not include the moral side of the issue. It is up to military commanders to decide whether the moral and political considerations outweigh the legal and military ones. Still, civilians remain civilians regardless of whether they are utilized by the defending party to deter attacks or not.

(C) [2017], The Author(s). This is an Open Access article distributed under the terms of the Creative Commons Attribution License (CC-BY)

4.0 https://creativecommons.org/licenses/by/4.0/, which permits unrestricted use, distribution, and reproduction in any medium, provided the original author and source are credited.

${ }^{159}$ Newton and May (n 115) 217-218. 